Volume 13, Nomor 2, November 2021, pp 344-351 Copyright (C) 2017

Jurnal Akuntansi, Program Studi Akuntansi, Fakultas Bisnis,

\begin{tabular}{lll|l|l} 
Universitas Kristen & Maranatha. ISSN 2085-8698 & e-ISSN 2598-4977.
\end{tabular}

http://journal.maranatha.edu

\title{
Dampak Covid-19 Terhadap Potensi Pajak Hiburan dan Kontribusi Terhadap Pendapatan Asli Daerah Kota Batu (Studi Kasus Dinas Pendapatan Kota Batu)
}

\author{
Marianus Vianey Dede ${ }^{1}$ \\ Universitas Tribhuwana Tunggadewi Kota Malang Indonesia \\ dedevianey4@gmail.com \\ Poppy Indrihastuti ${ }^{2}$ \\ Universitas Tribhuwana Tunggadewi Kota Malang Indonesia \\ dedevianey4@gmail.com \\ Yayuk Sulistyowaty ${ }^{3}$ \\ Universitas Tribhuwana Tunggadewi Kota Malang Indonesia
}

\begin{abstract}
This study aims to determine the impact of Covid-19 on the potential for entertainment tax and its contribution to the local revenue of Batu City. The research method used is a qualitative method with an interpretive approach. This research takes the object of Batu City Revenue Service. The data sources are primary data and secondary data. This research data collection technique using observation, interview and documentation techniques. this research, the results found can be concluded that, the potential for entertainment tax from year to year plays an important role with the aim of increasing PAD. The contribution of the entertainment local tax to PAD in 2020, in the situation of the Corona-19 Virus, has decreased, and also Entertainment tax revenue from 2018-2020 has not been optimal based on the existing potential
\end{abstract}

Keywords : Covid-19, Entertainment Tax, Contribution, and PAD Kota Batu

\begin{abstract}
Abstrak
Adapun tujuan dari riset ini ialah, untuk mengetahui adanya sebuah dampak dalam situasi pandemi pada potensi terhadap pajak hiburan, serta kontribusi dalam memaksimalkan PAD di Kota Batu. Metode penelitian yang digunakan dalam riset ini menggunakan metode deskriptif kualitatif dengan pendekatan Interpretatif. Obyek dalam riset ini ialah pada Dinas Pendapatan Kota Batu. Sumber data yang digunakan dalam riset ini ialah data sekunder serta data primer, teknik pengumpulan data yang akan digunakan dalam riset ini ialah observasi, interview serta dokumentasi. Dalam riset ini, hasil yang ditemukan dapat disimpulkan bahwa, potensi pajak hiburan dari tahun ke tahun sangat berperan penting dengan tujuan untuk dapat meningkatkan PAD. Kontribusi pajak daerah hiburan pada PAD di tahun 2020, dalam situasi


Virus Corona-19 mengalami penurunan, dan juga penerimaan pajak hiburan dari tahun 20182020 belum optimal berdasarkan potensi yang ada.

\section{Kata Kunci : Covid-19, Pajak Hiburan, Kontribusi, dan PAD Kota Batu}

\section{Pendahuluan}

Wabah Virus Corona yang melanda dunia, salah satunya negara Republik Indonesia dapat dikatakan sebagai jenis penyakit yang sangat berbahaya. Salah satu penyakit yang muncul diakibatkan oleh wabah Virus Corona yang terbaru bernama Sindrom Pernapasan Akut Berat 2 (SARS-CoV-2). Wabah Virus Corona yang menyebar di republik ini pada awalnya dapat terdeteksi pada tahun 2020, tepatnya pada tanggal 2 Maret terdapat dua orang positif terpapar Virus Corona yang diantaranya pada Negara Jepang, sedangkan baru pada tanggal 9 April wabah ini sudah menyebar di Indonesia.

Sebagai tanggapan terhadap wabah ini, terdapat beberapa tempat yang yang telah menetapkan PSBB. Hal ini memberikan dampak kepada masyarakat di tempat yang dilakukan PSBB, segala macam bentuk kegiatan harian dihentikan dan diarahkan untuk tetap berada di rumah. Aktivitas masyarakat menjadi terhenti, sekolah-sekolah diliburkan dan dibuat sekolah online oleh pemerintah, pekerjapekerja swasta di rumahkan dan pegawai negeri di potong jam kerja dan gaji.

Imbas dari Covid-19 yang sedang menyerang dan berkembang di Indonesia terhadap masyarakat, telah mendatangkan banyak keresahan dan kekacauan dalam segala aspek kehidupan masyarakat maupun negara. Covid-19 ini bukan saja menyerang kesehatan masyarakat Indonesia tapi juga di bidang Perekonomian Indonesia, yang dampaknya sangat terasa oleh masyarakat maupun pemerintahan. Akibat dari Covid-19 membuat banyak gaji karyawan yang di potong atau diturunkan bahkan ada juga karyawan yang di PHK karena pendapatan perusahaan menurun dan hampir tidak mampu membayar gaji semua karyawannya.
Dampak yang paling terasa yaitu mengenai pendapatan masyarakat itu sendiri, perusahaan berskala besar maupun kecil dan juga pemerintah. Dengan menurunnya pendapatan ini membuat perusahaanperusahaan kekurangan dana untuk melanjutkan kegiatan atau aktivitasaktivitasnya. Apalagi jenis perusahaan hiburan akan lebih terasa dampaknya pada situasi Covid-19 ini, banyak pengunjung atau wisatawan yang tidak berkunjung karena ada juga peraturan yang dikeluarkan pemerintah mengenai larangan bagi masyarakat untuk berkerumun. Ini membuat perusahaan hiburan mengalami penurunan pengunjung yang mengarah pada pendapatan perusahaan. Penurunan pendapatan ini menjadikan perusahaan pun susah untuk membayar pajaknya, padahal pajak hiburan memberikan kontribusi besar terhadap pendapatan daerah.

Indrihastuti, Poppy dan Amaniyah, Mulimatul (2020) menyatakan bahwa pajak merupakan salah satu tindakan dalam melakukan proses pembayaran yang dapat dikatakan sangat wajib, yang mana akan dikeluarkan oleh negara-negara masyarakat yang mana berdasarkan dengan UU. Disamping itu pajak dapat dikatakan sebagai salah satu pemasukan yang terbesar pada negara, karena tanpa adanya pajak salah satu negara dapat dinyatakan akan mati atau tidak berkembang secara efektif.

Kota Batu dapat dinyatakan sebagai salah satu kota destinasi wilayah wisata yang terdapat banyak tempat hiburan dan sering dijadikan pilihan wisatawan untuk berkunjung dan menghabiskan waktu liburan mereka. Indrihastuti, Poppy dan Amaniyah, Mulimatul (2020) menyatakan bahwa PAD dapat dinyatakan sangat wajib terinteraksi serta terkoordinasi berdasarkan dengan sebuah pemasukan pada daerah. 
Apabila sumber PAD tertata dengan baik serta benar, maka secara tidak langsung pihak pemerintah daerah setempat dapat melakukan penyusunan pembiayaan yang akan diprioritaskan untuk daerahnya. Pendapatan bersumber dari PAD, anggaran dalam sebuah perimbangan finansial antara pemerintah pusat serta pemerintah daerah .

Menurut Indrihastuti, Poppy dan Amaniyah, Mulimatul (2020) pajak daerah dapat ditagih berdasarkan setiap daerah serta dapat dimanfaatkan demi keperluan daerah. Adapun sumber anggaran yang berlebih, secara tidak langsung akan masuk ke pemerintah pusat, akan tetapi apabila pihak pemerintah menganalisa tingkat kebutuhan disetiap daerah dengan baik serta mempunyai anggaran bersumber dari dana daerah nya. Jadi apabila wajib pajak membayar pajak secara teratur maka sangat berpengaruh juga terhadap pertumbuhan daerah tersebut.

Salah satu hiburan dapat dikatakan sebagai sebuah aktivitas yang sangat efektif yang bisa saja dalam bentuk benda serta tempat dengan tujuan ialah untuk dapat menghibur. Pada dasarnya hiburan berwisata juga dapat dinyatakan sebagai salah satu tindakan untuk menghibur, yang mana akan menjelajahi alam dalam memahami sebuah budaya seperti membuat kerajinan dan keterampilan. Hiburan juga dapat dinyatakan sebagai salah satu film, musik serta permainan.

Destinasi hiburan yang berada di wilayah Kota Batu ialah Jatim Park, BNS, Predator Fun Park serta Wisata Selecta dan lain-lain. Selain tempat wisata, tempattempat umum lain nya seperti Panti Pijat, Club Karaoke, dan lain nya membuktikan bahwa perusahaan hiburan pada saat-saat sekarang telah berkembang pesat dan menjadi salah satu tongkat pendorong perekonomian. Dengan demikian pajak yang diberikan perusahaan-perusahaan tersebut menjadi pendapatan daerah Kota Batu.

\section{Tinjauan Pustaka}

Pengaruh Pandemik Covid-19 Terhadap Pendapatan Tempat Wisata dan Kinerja Karyawan Pariwisata di Jakarta (Studi Kasus Seluruh Karyawan Pariwisata di Jakarta)

Menurut Soehardi, Diah Ayu Permatasari, Janfry Sihite (2020), apabila wabah Virus Corona berkepanjangan maka secara tidak langsung akan memberikan sebuah pengaruh yang sangat signifikan pada tingkat pendapatan di sebuah tempat wisata. Pada indikator dalam sebuah penghasilan pada tempat wisata serta tempat hiburan yang cukup dominan ialah jumlah tingkat penerimaan PAD dari sektor hiburan serta wisata ialah pengaruh tingkat penerimaan PAD bersumber dari pajak wisata serta hiburan.

Peran Dinas Pendapatan Daerah Kota Batu Dalam Upaya Peningkatan Pajak Hiburan (Studi Kasus Dinas Pendapatan Daerah Kota Batu)

Menurut Ahmad Ardy Wijaya,Mochamad Djudi, Mirza Maulinarhadi R (2015), hasil dari penelitian ini menunjukkan bahwa adanya peningkatan dalam sebuah penerimaan pada pajak hiburan berdasarkan pada ekstensifikasi serta intensifikasi yang mana akan dapat meningkat berdasarkan dengan pada sebuah penerimaan pada sebuah pajak hiburan berdasarkan dengan sebuah tindakan dalam pemungutan.

Kontribusi Pajak Hiburan Dalam Meningkatkan Pendapatan Asli Daerah (PAD) Di Kota Malang (Studi Kasus Dinas Pendapatan Daerah Kota Malang) Menurut Dara Rizky Supriadi, Dwiatmanto, Suhartini Karjo (2015), hasil dari penelitian ini menunjukkan sebuah pemasukan terhadap pajak hiburan pada pajak daerah pada tahun yang keempat, mulai dari tahun 2011-2014 berjumlah 1,91\%, 1,25\%, 1,97\% serta 1,87\% serta Pemda Kota Malang berdasarkan dengan data yang bersumber dari DISPENDA melaksanakan beberapa 
upaya ekstensifikasi WP serta intensifikasi pajak, akan tetapi dalam upaya tersebut sama sekali belum baik secara maksimal.

\section{Analisis Potensi Pendapatan Pajak Hiburan Dan Kontribusinya Terhadap Pendapatan Pajak Daerah}

Menurut Asrul Firmansyah, Srikandi Kumadji, Achmad Husaini (2016) yang menyatakan bahwa kontribusi terhadap salah satu peningkatan terhadap PAD di Desa Tulungagung di tahun 2012-2014 dapat dinyatakan dalam kategori yang masih kurang baik. Tingkat kontribusi yang terbesar pada periode 2013 meningkat sebesar $1,75 \%$. PAD Tulungagung alangkah baiknya dapat dibuat dalam pengamatan secara tidak langsung berkala pada tingkat penyelenggaraan terhadap sebuah tempat hiburan serta dapat meningkatkan sosialisasi terhadap pihak penyelenggaraan tempat hiburan yang baru dalam memenuhi kewajiban perpajakan.

Pengaruh Pemungutan Pajak Hotel Dan Pajak Hiburan Terhadap Peningkatan Pendapatan Asli Daerah Kota Medan.

Sebagaimana yang dikatakan oleh Nabila Suha Bahmid , Herry Wahyudi (2018), tingkat pemungutan pada pajak hotel dapat memberikan sebuah pengaruh pada peningkatan PAD di Kota Medan

\section{Metode Penelitian}

Desain yang digunakan pada riset ini ialah deskriptif kualitatif, pada riset ini fokus yang dilakukan pada Dispenda Kota Batu, terkait dengan Dampak Covid-19 terhadap potensi pajak hiburan serta sebuah kontribusi terhadap PAD. Teknik pengumpulan data yang dilakukan dalam riset ini ialah interview, observasi serta dokumentasi, sedangkan sumber data yang digunakan dalam riset ini ialah data sekunder serta data primer, sedangkan salah satu teknik analisis data yang digunakan ialah bersifat induktif atau kualitatif, dan hasil penelitian kualitatif lebih menekankan makna dari pada generalisasi.

\section{Hasil Penelitian dan Pembahasan}

Data dalam sebuah penargetan serta sebuah realisasi terhadap pajak hiburan dalam kurun waktu tiga tahun ialah dari tahun 2018-2020. Oleh karena itu sebuah realisasi terhadap pajak hiburan dapat disajikan pada tabel berikut ini :

Tabel 1

Target dan Realisasi Pajak Hiburan Tahun 2018 -2020

\begin{tabular}{|c|c|c|c|}
\hline Tahun & Target & Realisasi & $\%$ \\
\hline 2018 & $17.451 .000 .000,00$ & $26.327 .936 .517,00$ & 150,87 \\
\hline 2019 & $30.699 .999 .999,00$ & $32.117 .335 .069,00$ & 104,62 \\
\hline 2020 & $13.325 .364 .000,00$ & $14.251 .004 .321,00$ & 106.95 \\
\hline \multicolumn{4}{|c|}{ Sumber : Badan Keuangan Daerah } \\
\hline
\end{tabular}

Sebagaimana dari hasil perhitungan pada tabel tersebut, sehingga dapat diketahui bahwa pajak hiburan di Kota Batu dari tahun 2018-2019 mengalami peningkatan yang pesat. Sedangkan pada tahun 2020 mengalami kenaikan yang sangat kecil. Pada tahun 2018 sebesar Rp.26.327.936.517,00, pada tahun 2019 meningkat sebesar Rp. 32.117.335.069,00 sedangkan pada tahun 2020 pada masa pandemi hanya meningkat sebesar Rp. 14.251.004.321,00.

Data Penerimaan Pendapatan Asli Daerah Kota Batu Tahun 2018-2020.

Data penerimaan Pendapatan Asli Daerah selama 3 tahun dari tahun 2018-2020 Badan Keuangan Daerah Kota Batu dapat disajikan pada tabel berikut ini:

Tabel 2

Target dan Realisasi PAD Tahun 20182020

\begin{tabular}{|c|c|c|c|}
\hline Tahun & Target & Realisasi & Persen (\%) \\
\hline $\mathbf{2 0 1 8}$ & $114.973 .569 .516,00$ & $142.879 .431 .151,04$ & 124,27 \\
\hline $\mathbf{2 0 1 9}$ & $131.362 .767 .077,00$ & $161.289 .933 .114,00$ & 122,78 \\
& & & \\
\hline $\mathbf{2 0 2 0}$ & $89.547 .954 .383,00$ & $115.401 .468 .724,00$ & 128,87 \\
\hline \multicolumn{3}{|c|}{ Sumber : Badan Keuangan Daerah } \\
\hline
\end{tabular}


Sebagaimana dari hasil perhitungan pada tabel tersebut, sehingga dapat diketahui bahwa pada tingkat persentase dalam sebuah PAD Kota Batu dari tahun 2018-2019 terdapat peningkatan, sedangkan pada tahun 2020 targetnya mengalami penurunan akibat dari dampak Covid-19, tapi realisasinya mengalami kenaikan walaupun kecil. Pada tahun 2018 sebesar Rp.142.879.431.151,04. Pada tahun 2019 sebesar Rp. 161.289.933.114,00. Sedangkan pada tahun 2020 sebesar Rp. 115.401.468.724,00.

\section{Kontribusi Pajak Hiburan Terhadap PAD}

Kota Batu menjadi salah satu tujuan untuk berwisata, karena mempunyai alam yang bagus dalam meningkatkan PAD di bagian kepariwisataan. Oleh karena itu dapat dinyatakan bahwa sebuah Kontribusi Pendapatan Asli Daerah dari sektor pariwisata seharusnya sangat besar. Namun realisasi pajak hiburannya hanya mampu memberi kontribusi yang kecil. Sejak tahun 2018-2019. Salah satu pemasukan ialah pajak hiburan pada tingkat PAD meningkat, sedangkan pada tahun 2020 terdapat wabah Covid-19 yang mana memberikan dampak yaitu pemasukan PAD mengalami penurunan. Oleh karena itu tingkat pemasukan pajak hiburan dapat disajikan pada tabel berikut ini :

\section{Tabel 3}

\section{Kontribusi Pajak Hiburan terhadap} PAD tahun 2018-2020

\begin{tabular}{|l|l|l|l|l|}
\hline Tahun & Pajak Hiburan & PAD & Kontribusi & Keterangan \\
\hline 2018 & $26.327 .936 .517,00$ & $142.879 .431 .151,04$ & $18,43 \%$ & Baik \\
\hline 2019 & $32.117 .335 .069,00$ & $161.289 .933 .114,00$ & $20,00 \%$ & Baik \\
\hline 2020 & $18.624 .482 .157,00$ & $114.618 .820 .621,00$ & $12,34 \%$ & Kurang baik \\
\hline \multicolumn{5}{|c|}{ Sumber : Hasil Pengolahan Data } \\
\hline
\end{tabular}

Berikut perhitungan kontribusi pajak hiburan terhadap Pendapatan Asli Daerah Kota Batu.

Kontribus $=\frac{\text { Pajak Hiburan }}{P A D} \times 100 \%$
Tabel 4

Perhitungan Kontribusi Pajak Hiburan Terhadap Pendapatan Asli Daerah Kota Batu 2018-2020

\begin{tabular}{|l|c|}
\hline Tahun 2018 & Kontribusi $=\frac{26.327 .936 .517,00}{142.879 .431 .151,04}$ \\
\hline Tahun 2019 & Kontribusi $=\frac{32.117 .335 .069,00}{161.289 .933 .114,00}$ \\
\hline Tahun 2020 & Kontribusi $=\frac{100 \%=18,43 \%}{115.401 .004 .321,00}$ \\
\hline & Sumber : Hasil Pengolahan Data
\end{tabular}

Sebagaimana pada hasil perhitungan pada tabel tersebut, sehingga dapat dinyatakan bahwa pada pajak hiburan dalam PAD dapat tergolong meningkat. Pada periode 2018 terdapat pajak hiburan dapat memberikan pemasukan sangat pesat sebesar $18,43 \%$, pada tahun 2019 mengalami peningkatan kontribusi sebesar $20,00 \%$, sedangkan pada tahun 2020 mengalami penurunan kontribusi, imbas dari COVID-19 sebesar $12,34 \%$.

\section{Potensi Pajak Hiburan}

Potensi pajak hiburan adalah kemampuan yang dapat digali dan di kembangkan yang diperoleh dari pajak hiburan. Pada PAD, terdapat 3 klasifikasi potensi hiburan yang diambil oleh peneliti dengan total potensi per tahun :

Tabel 5

Total Tempat Hiburan Kota Batu

\begin{tabular}{|c|c|c|c|c|}
\hline $\mathrm{No}_{0}$ & Pajak Hiburan & 2018 & 2019 & 2020 \\
\hline 1 & Karaoke & 8 & 8 & 8 \\
\hline 2 & Permainan Ketangkasan & 4 & 4 & 4 \\
\hline \multirow[t]{2}{*}{3} & Panti Pijat & 12 & 12 & 12 \\
\hline & Total & 25 & 25 & 25 \\
\hline
\end{tabular}

Potensi Pajak Hiburan di Kota Batu selama tahun 2018-2020 masih tetap sama dari tahun ke tahun. Pada tabel di atas dicantumkan bahwa potensi pajak hiburan terbesar adalah Panti Pijat, dimana potensi pajak Hiburan Panti Pijat masih tetap stabil meskipun pemasukan menurun di tengah pandemi ini. Berikut ini dijelaskan mengenai 
perhitungan Potensi Pajak Hiburan dari setiap jenis Hiburan dari tahun 2018-2020.

\section{Potensi Pajak Hiburan Kota Batu}

Potensi Pajak Hiburan Kota Batu dapat diperoleh dari hiburan jenis Karaoke, Panti Pijat dan Ketangkasan. Dari Potensi Pajak Hiburan yang ada diharapkan mampu memberikan penerimaan yang besar terhadap Pendapatan Asli Daerah Kota Batu. Jumlah Potensi di Kota Batu tahun 20182019 rata-rata mengalami penurunan, begitu juga dengan total pengunjungnya. Pada tahun 2020 karena masa pandemi dan di tetapkan PSBB, maka potensi pajak hiburan mengalami penurunan karena kurangnya pengunjung.

\section{Tabel 6}

Potensi Pajak Hiburan Terhadap PAD Tahun 2018-2020

\begin{tabular}{|c|c|c|c|c|}
\hline Tahun & $\begin{array}{c}\text { Potensi Pajak } \\
\text { Hiburan }\end{array}$ & PAD & Kontribusi & Keterangan \\
\hline 2018 & $2.550 .236 .500,00$ & $142.879 .431 .151,04$ & $2,65 \%$ & Sangat Kurang \\
\hline 2019 & $2.744 .635 .750,00$ & $161.289 .933 .114,00$ & $1,72 \%$ & Sangat Kurang \\
\hline 2020 & $1.200 .639 .625,00$ & $115.401 .468 .724,00$ & $1,40 \%$ & Sangat Kurang \\
\hline \multicolumn{4}{|r}{ Sumber : Hasil Pengolahan Data } \\
\hline
\end{tabular}

Berikut perhitungan kontribusi potensi pajak hiburan terhadap Pendapatan Asli Daerah Kota Batu.

Kontribusi $=\frac{\text { Potensi Pajak Hiburan }}{\text { Realisasi Penerimaan } P A D} \times 10$

\begin{tabular}{|c|c|}
\hline Tahun 2018 & Kontribusi $=\frac{2.950 .236 .500,00}{142.879 .431 .151,04} \llbracket 100 \%=2,65 \%$ \\
\hline Tahun 2019 & Kontribusi $=\frac{2.744 .635 .750,00}{161.289 .933 .144,00} \mathbb{1} 100 \%=1,72 \%$ \\
\hline Tahun 2020 & Kontribusi $=\frac{1.200 .639 .625,00}{115.401 .468 .724,00} \mathbb{1} 100 \%=1,40 \%$ \\
\hline
\end{tabular}

Sebagaimana pada hasil perhitungan pada tabel tersebut, sehingga dapat dinyatakan bahwa pajak hiburan yang diterima oleh Badan Keuangan Daerah Kota Batu hanya memberi kontribusi yang kecil terhadap Pendapatan Asli Daerah. Dilihat dari banyak nya tempat-tempat yang tersedia seharusnya dari tahun 2018-2019 mampu memberikan kontribusi yang besar. Apalagi ditambah dengan adanya pandemi Covid-19 di tahun 2020 membuat kontribusi Pajak Hiburan terhadap PAD semakin menurun. Pajak Hiburan memberikan kontribusi sebesar 1,20\% pada tahun 2018, pada tahun 2019 mengalami tingkat penerimaan sebesar $1,72 \%$. Sedangkan di masa pandemi tahun 2020 mengalami penurunan sebesar $1,40 \%$.

\section{Hasil Penelitian}

Pajak Daerah pada Kota Batu ialah pajak hotel, pajak reklame, pajak restoran serta pajak penerangan dan lain-lain. Dengan adanya beragam jenis pajak daerah Kota Batu diharapkan untuk mampu melaksanakan penerimaan yang cukup tinggi yang mana nantinya, dapat dimanfaatkan untuk pembangunan Kota Batu.

Penelitian ini membandingkan dari hasil observasi sesuai dengan informasi yang dimiliki pada BKD dan Dinas Pariwisata. Informasi yang diperoleh dari Dinas Pendapatan adalah target dan realisasi pada tahun 2018-2020. Menurut data yang diperoleh, target dan realisasi pajak hiburan dari tahun 2018-2019 cukup baik karena selalu melebihi dari target yang ditentukan. Akan tetapi di tahun 2020 pajak hiburan mengalami penurunan pendapatan akibat dampak Covid-19.

Hal ini membuktikan bahwa pemasukan pada pajak hiburan terhadap PAD dinyatakan mengalami penurunan dalam penerimaan potensi pajak hiburan pada saat masa pandemi Covid-19 tahun 2020 yaitu sebanyak Rp.1.200.639.625,00. Hal ini dikarenakan banyak tempat-tempat hiburan yang ditutup selama pandemi Covid-19, ditambah lagi ditetapkan PSBB membuat penerimaan potensi pajak hiburan sangat menurun, yang berdampak pada penerimaan pajak hiburan pada Kota Batu. 
Faktor-faktor yang Mempengaruhi Penerimaan Pajak Hiburan Kota Batu 1. Kesadaran Wajib Pajak

Tingkat Kesadaran pada WP sangatlah diperlukan, karena pajak dapat dikatakan sebagai sumber anggaran yang terpenting dalam meningkatkan pembangunan daerah. Jika kesadaran wajib pajak tinggi maka wajib pajak akan membayarkan pajak terutangnya sesuai dengan keadaan yang sebenarnya, sehingga BKD dapat memperoleh penerimaan pajak secara maksimal. Dan perlu juga dilakukan penyuluhan oleh petugas BKD kepada wajib pajak mengenai manfaat dari pemungutan pajak tersebut, sehingga mampu memberikan wawasan kesadaran yang tinggi bagi wajib pajak dalam membayarkan pajak.

\section{Pengawasan}

Dalam upaya meningkatkan pengawasan penerimaan pajak terhadap petugas yang terjun langsung untuk mengawasi kegiatan hiburan. Berdasarkan peningkatan pengawasan dapat diketahui, dalam sebuah pekerjaan apakah dapat dibuat aturan ditetapkan atau tidak. Selain itu pengawasan dapat berfungsi sebagai kontrol untuk mengurangi kesalahan yang dapat mengurangi pendapatan daerah.Pengawasan tidak hanya untuk wajib pajak dan objek pajak sajah, melainkan juga kepada petugas pemungutan pajak. Dalam pengawasan ini, bertujuan untuk memperoleh penerimaan pajak yang maksimal di tengah wabah Covid-19.

\section{Strategi Pemerintah Dalam Meningkatkan Penerimaan Pajak Hiburan Kota Batu Di Masa Covid-19}

Salah satu upaya Pemda Kota Batu dalam meningkatkan penerimaan pajak hiburan yang berada di Kota Batu di masa pandemi ini harus di lakukan secara terus-menerus dan berjalan, agar penerimaan pajak hiburan dapat stabil dan bahkan diharapkan akan meningkat. Sehingga pada tahun yang akan datang di masa pandemi ini penerimaan pajak hiburan terdapat memberikan sebuah pemasukan yang cukup tinggi pada PAD dalam masa Covid-19 ini. Berikut upaya dalam meningkatkan Penerimaan Pajak Hiburan di masa Pandemi ini :

1. Strategi melalui Ekstensifikasi

Ekstensifikasi adalah kegiatan yang berkaitan dengan penambahan atau pencarian, dalam hal ini pada sebuah objek yang dikatakan baru. Sasaran dalam hasil pembahasan berdasarkan kegiatan ekstensifikasi ialah dalam sistem pengendalian pada sebuah pendapatan berdasarkan pajak dalam memaksimalkan penambahan PAD, misalnya dengan memberikan NPWP. Selain itu, melakukan panggilan terhadap potensi pajak yang baru.

2. Strategi melalui Intensifikasi

Intensifikasi adalah suatu cara yang digunakan dalam memaksimalkan terkait sistem pendapatan yang bersumber dari sistem penerimaan dengan cara mengevaluasi, mengkaji kembali, serta pembenahan dalam pembayaran hingga pelaporan.

3. Protokol Kesehatan (PROKES)

Diharapkan pemerintah Kota Batu selalu memantau aktivitas pengunjung ke tempat wisata dan selalu menetapkan sebuah protokol kesehatan, yang mana menggunakan masker atau mengambil jarak antara manusia dan selalu memakai handsanitizer.

\section{Simpulan}

Sebagaimana dari hasil analisa serta pembahasan yang telah dipaparkan pada bab-bab sebelumnya, dapat diambil sebuah kesimpulan bahwa pemasukan PAD yang bersumber dari pajak hiburan terhadap PAD pada tahun 2020 di masa pandemi Covid 19 , mengalami penurunan sebesar $12,34 \%$. Selain itu, Penerimaan pajak hiburan dari tahun 2018-2020 belum optimal berdasarkan potensi yang ada. Ditambah lagi dengan adanya Covid-19 menurunkan potensi yang ada karena kurang nya pengunjung. 


\section{Daftar Pustaka}

Bahmid Nabila Suha, Herry Wahyudi. 2018. Pengaruh Pemungutan Pajak Hotel Dan Pajak Hiburan Terhadap Peningkatan Pendapatan Asli Daerah Kota Medan, Jurnal Riset Akuntansi \& Bisnis Vol. 18 No.1

Embun Bening Diniari. 2018. Teknik Mengumpulkan Data pada Penelitian Kualitatif. Dipetik Oktober 27,2020, dari https://blog.ruangguru.com.

Firmansyah Asrul, Kumadji Srikandi,Husaini Achmad. 2016. Analisis Potensi Pendapatan Pajak Hiburan Dan Kontribusinya Terhadap Pendapatan Pajak Daerah, Jurnal Perpajakan (Jejak), Vol. 8 No. 1.

Hifzahamdan, 2017. Definisi Istilah dalam Penelitian Kualitatif. Dipetik Oktober 27,2020, dari https://hifzahamdanblog.wordpress.co $\mathrm{m}$

Hidayat Anwar. 2012. Penelitian Kualitatif. Dipetik Oktober 29,2020, dari https://www.statistikian.com.I

Indrihastuti Poppy, Amaniyah Mulimatul, 2020. Peran Pajak Reklame Terhadap Pendapatan Kota Malang.

Negara Indonesia. 2020. Pandemi COVID19 Menurut Negara Indonesia 2020. Dipetik November 3, 2020, dari id.wikipedia.org/wiki/PandemiCOVID-19 di-Indonesia.

Peraturan Walikota Batu. 2020. Tata Cara Pemungutan Pajak Hiburan 2020. Dipetik Oktober 27,2020, dari https://jdih.batukota.go.id/peraturanwalikota-batu-nomor-31-tahun-20202.html.

Ridwan. 2013. Dasar-Dasar Statistika. Bandung : Alfabeta.

Soehardi, Diah Ayu Permatasari, Janfry Sihite. 2020. Pengaruh Pandemik Covid-19 Terhadap Pendapatan Tempat Wisata dan Kinerja Karyawan Pariwisata di Jakarta, Jurnal Kajian Ilmiah: (JKI), Edisi khusus No.1 (Juli 2020), Hal :1-14.
Supriadi Rizky Dara,Dwiatmanto, Karjo Suhartini. 2015. Kontribusi Pajak Hiburan Dalam Meningkatkan Pendapatan Asli Daerah (Pad) Di Kota Malang, Jurnal Perpajakan (JEJAK), Vol.1 No.1.

Wijaya Ahmad, Mochamad Djudi, Maulinarhadi R Mirza. 2015. Peran Dinas Pendapatan Daerah Kota Batu Dalam Upaya Peningkatan Pajak Hiburan, Jurnal Perpajakan (JEJAK), Vol.7 No.1.

Zsazya, 2020. Pajak Hiburan. Dipetik Oktober 27, 2020, dari https://www.online pajak.com/tentangpajak-pribadi/pajak-hiburan. 